УAK 658.5.016:336.748.12

\author{
S. Khalatur, \\ Doctor of Economic Sciences, associate professor \\ Professor of Finance, Banking and Insurance Department, \\ Dnipro State Agrarian and Economic University \\ ORCID ID: 0000-0001-8331-3341 \\ O. Dubovych, \\ PhD in Law, Associate Professor of Entrepreneurship and Law Department \\ Poltava State Agrarian Academy \\ ORCID ID: 0000-0003-3390-1393 \\ V. Velychko, \\ student of gr. MGFBSz-1-18, Dnipro State Agrarian and Economic University \\ ORCID ID: 0000-0002-8298-2962
}

DOI: $10.32702 / 2306-6792.2019 .24 .50$

\title{
CONCEPTUAL BASIS OF FINANCIAL MANAGEMENT OF LIQUIDITY AND SOLVENCY OF ENTERPRISE
}

\author{
С. М. Халатур, \\ А. е. н., доцент, професор кафедри фінансів, банківської справи та страхування, \\ Аніпровський державний аграрно-економічний університет \\ О. В. Аубович, \\ к. ю. н., доцент кафедри підприємництва і права, \\ Полтавська державна аграрна академія, \\ В. П. Величко, \\ студентка гр. МгФБСз-1-18, Аніпровський державний аграрно-економічний університет

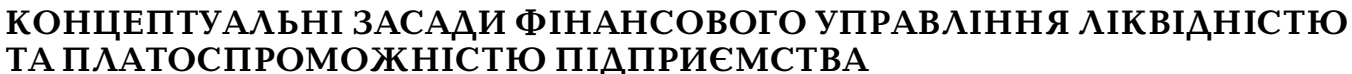

The main conceptual principles of financial management of agricultural enterprises' liquidity and solvency are investigated in the article. The purpose is to identify the relationship between the competitive strategies of agricultural enterprises and their financial indicators of liquidity and solvency. To achieve the goal of the study was divided into two main phases. First, the relationship between competitive strategies of agricultural enterprises and their financial results was examined. Four strategic variables were selected to represent competitive strategies: type of activity; the degree of diversification; liquidity level; and the level of solvency. The financial performance of an agricultural enterprise was represented by five variables: return on assets, return on equity; asset turnover; current liquidity; fast liquidity. The following key variables were selected to represent agricultural enterprise strategies: direction; method; diversification; financial planning; functionality; resource; financial performance indicators; and determining indicators of financial and economic activity.

The results showed a significant correlation between the competitive strategies of agricultural enterprises and their financial indicators of liquidity and solvency. The type of activity is related to profitability, solvency and liquidity. Profitability was also influenced by the level of production diversification. However, the degree of diversification and scale of production had strong links with turnover; it was found that agricultural enterprises consider expansion through internal expansion as their most important development strategy. Innovation and advanced technology were seen as important functionalities of the strategy. Management, skilled workers and cash are the three most critical resources. Cash flow was considered to be the most important financial performance indicator, although the market was seen as the most important determining indicator of financial performance of liquidity and solvency.

У статті досліджено основні концептуальні засади фінансового управління Аіквідністю та платоспроможністю сільськогосподарських підприємств. Мета - виявити взаємозв'язок між конкурентними стратегіями сільськогоспоАарських підприємств та їхніми фінансовими показниками ліквідності та платоспроможності. Аля досягнення мети дослідження було розділено на Аві основні фази. По-перше, досліджувався взаємозв'язок між конкурентними стратегіями сільськогосподарських підприємств та їхніми фінансовими результатами. Було обрано чотири стратегічні змінні, які представляють конкурентні стратегії: виА Аіяльності; ступінь диверсифікації; рівень ліквідності і рівень 
платоспроможності. Фінансову результативність сільськогосподарського підприємства було представленао п'ятьма змінними: рентабельність активів, рентабельність власного капіталу; оборотність активів; поточна ліквідність; швидка ліквідність. Наступні основні змінні було обрано Аля представлення стратегій сільськогосподарських підприємств: напрям; метод; Аиверсифікація; фінансове планування; функціональність; ресурси; фінансові індикатори продуктивності; визначальні показники фінансово-господарської діяльності.

Результати показали суттєвий взаємозв'язок між конкурентними стратегіями сільськогосподарських підприємств та їх фінансовими показниками ліквідності і платоспроможності. Вид Аіяльності має відношення до рентабельності, платоспроможності та ліквідності. На прибутковість впливав і рівень диверсифікації виробництва. ОАнак ступінь Аиверсифікації та масштаби виробництва мали сильний характер зв'язків із оборотом, було встановлено, що сільськогосподарські підприємства вважають розширення шляхом внутрішнього розширення як їх найважливішу стратегію розвитку. Інновації та передові технології розглядалися як важливий функціонал стратегії. Менеджмент, кваліфіковані працівники та грошовий капітал є іх трьома найбільшими критичними ресурсами. Грошовий потік розглядався як найважливіший фінансовий показник ефективності, хоча стан ринку сприймався як найбільш важливий визначальний індикатор фінансових показників ліквідності та платоспроможності.

Key words: liquidity ratios, strategy, competitive advantages, management.

Ключові слова: коефічієнти ліквідності, стратегія, конкурентні переваги, управління.

\section{INTRODUCTION}

The dynamic development of economic entities, the uncertainty of modern economic, financial and political space impedes the ability of an enterprise to fulfill its obligations in full within the prescribed period. Issues of timely payment for both shipped products and for material values, financial resources received from external counterparts become important in the settlement system; timely payment of staff salaries and payment of taxes, fees and other payments to the budget and extra budgetary funds.

Under the influence of instability of the external environment, the growth of production volumes is reduced, the types of activity are reduced, investment processes are slowed down and terminated. Agricultural enterprises are not able to support the achieved level of development. In this regard, there is a need to consider and substantiate the conceptual principles of financial management of the liquidity and solvency of the enterprise. The task of managing the solvency and liquidity of agricultural enterprises is becoming increasingly important.

Solvency and liquidity assessments are of interest to business executives, who must have reliable information about the availability of funds needed to pay salaries with staff, budget payments to financial institutions, loans to bank institutions, inventory and suppliers, as well as partner companies that provide commercial credit or resolve deferred payments, and bank institutions when determining the creditworthiness of borrowers. Therefore, the study of the conceptual principles of financial management of liquidity and solvency of the company is relevant.

\section{ANALYSIS OF RECENT RESEARCH AND PUBLICATIONS}

The topic of financial management of liquidity and solvency of an agricultural enterprise is quite relevant nowadays, so it is sufficiently developed in the literature on economic and financial analysis, financial management by many scientists, in particular in the works of Tsal-Tsalko Y.S., Tarasenko N.V., Negasheva E.V., Savitskaya G.V. etc.

Yes, Mohammad Fawzi Shubita (2019) writes that working capital is the difference between current assets and current liabilities of an enterprise. Thus, firms can increase liquidity by increasing their working capital. Current asset quality refers to the average time needed to convert current assets into cash. On the other hand, the quality of current assets takes into account whether the firm has sufficient assets to cover its liabilities and to ensure its regularity, sufficient and consistent cash flow to finance its activities.

Ruslan Mann, Victor Martinovich and Oksana Yakusheva (2018) write that current assets are one of the constituent assets of an enterprise whose condition and efficiency directly affect the efficiency of financial and economic activity. In terms of socio-economic changes in the national economy, the issue of lack of working capital, low turnover of current assets and insufficient liquidity is relevant for many enterprises. At the present stage of economic development, most agricultural enterprises are keenly short of current assets. The main reason for this phenomenon is the lack of effective management of them in the enterprise. Therefore, achieving a balance in the formation 
of working capital is a prerequisite for stable development of enterprises and improvement of the economic situation in Ukraine as a whole. Crisis management strategies and tactics and financial rehabilitation of enterprises include the formation of methods of effective management of working capital, which is to choose the optimal balance between the risk of investing current assets and their profitability as turnover and return on investment.

Ruslan Mann and Alexander Bilyk (2017) argue that current assets are one of the most important resources for the business of any company. Therefore, an effective process for managing working capital, including its formation, distribution and use, must be organized. Working capital management efficiency is an important part of the company's operations as it affects the production and marketing of goods and services, liquidity, solvency and profitability of the company. Favorable climatic conditions and the availability of large reserves of fertile soils create conditions for the development of agriculture, which is one of the most important sectors of the Ukrainian economy.

Therefore, in view of the current economic situation, research into the factors that affect the efficiency of managing working capital of agricultural enterprises is very important.

\section{RESULTS}

Substantiation of conceptual principles of financial management of liquidity and solvency of enterprises, consider the example of agricultural enterprises of Ukraine. In Table 1 it is shown the dynamics of production of basic crops by agricultural enterprises in Ukraine.

In order to determine whether an entity has enough money to meet its obligations, it is necessary to analyze the process of proceeds from economic activity and the formation of the balance after paying off obligations to the budget and offbudget funds, as well as dividend payments. Solvency analysis also requires careful analysis of the entity's accounts payable structure. It is made on the basis of a comparison of the volume of current liabilities with the presence of liquid assets. The results are calculated as liquidity ratios based on the information in the relevant financial statements.

The easiest way to determine the solvency at any date is based on the balance sheet of the enterprise. To do this, we first need to find out if there is a cash balance in the current account and other cash accounts. If these amounts are insignificant, you should also check the status of settlements with different creditors. The absence of overdue amounts is a good indication of a sustainable financial position. Debt study should begin with determining bank debt amounts, settlements with creditors for goods, jobs, services, budget and payroll workers. The main indicators of agricultural enterprises are analyzed in Table 2.

Table 1. Dynamics of production of basic crops by agricultural enterprises in Ukraine

\begin{tabular}{|l|l|l|l|l|l|l|l|l|}
\hline \multirow{2}{*}{ Cultures } & \multicolumn{7}{c|}{ Years } & 2017 in \% to \\
\cline { 2 - 9 } & 2010 & 2014 & 2015 & 2016 & 2017 & 2010 & 2016 \\
\hline \multicolumn{7}{|c|}{ Gross harvest, thousand tons } \\
\hline Cereals and legumes & 39271 & 63859,3 & 60125,8 & 66088 & 61917 & 157,66 & 93,69 \\
\hline Sugar beet (factory) & 13749 & 15734,1 & 10330,8 & 14011 & 14882 & 108,24 & 106,22 \\
\hline Sunflower & 6772 & 10133,8 & 11181,1 & 13627 & 12236 & 180,69 & 89,79 \\
\hline Potato & 18705 & 23693,4 & 20839,3 & 21750 & 22208 & 118,73 & 102,11 \\
\hline Vegetables & 8122 & 9637,5 & 9214,0 & 9415 & 9286 & 114,33 & 98,62 \\
\hline Fruits and berries & 1747 & 1999,1 & 2152,8 & 2007 & 2048 & 117,23 & 102,04 \\
\hline \multicolumn{7}{|c|}{ Yields, from 1 ha of harvested area } \\
\hline Cereals and legumes & 26,9 & 43,7 & 41,1 & 46,1 & 42,5 & 157,99 & 92,19 \\
\hline Sugar beet (factory) & 279 & 476,5 & 435,8 & 482 & 475 & 170,25 & 98,55 \\
\hline Sunflower & 15,0 & 19,4 & 21,6 & 22,4 & 20,2 & 134,67 & 90,18 \\
\hline Potato & 132 & 176,4 & 161,4 & 166 & 168 & 127,27 & 101,20 \\
\hline Vegetables & 174 & 207,8 & 206,1 & 211 & 208 & 119,54 & 98,58 \\
\hline Fruits and berries & 78,2 & 95,2 & 104,5 & 101,9 & 103,1 & 131,84 & 101,18 \\
\hline \multicolumn{7}{|c|}{ Area harvested, thousand ha } \\
\hline Cereals and legumes & 14576 & 14627,3 & 14640,9 & 14337 & 14560 & 99,89 & 101,56 \\
\hline Sugar beet (factory) & 492 & 330,2 & 237,0 & 291 & 314 & 63,82 & 107,90 \\
\hline Sunflower & 4526 & 5212,2 & 5166,2 & 6087 & 6061 & 133,92 & 99,57 \\
\hline Potato & 1412 & 1342,8 & 1291,0 & 1312 & 1323 & 93,69 & 100,84 \\
\hline Vegetables & 468 & 463,8 & 447,1 & 447 & 446 & 95,29 & 99,78 \\
\hline $\begin{array}{l}\text { Fruit and berry plantations } \\
\text { (in fruiting age) }\end{array}$ & 255 & 209,9 & 206,0 & 197 & 199 & 78,04 & 101,02 \\
\hline
\end{tabular}

Source: calculated according to State Statistics Service of Ukraine. 
Table 2. The main indicators of agricultural enterprises activity

\begin{tabular}{|c|c|c|c|c|c|c|c|}
\hline \multirow{2}{*}{ Indexes } & \multicolumn{5}{|c|}{ Years } & \multicolumn{2}{|c|}{2017 in $\%$ to } \\
\hline & 2010 & 2014 & 2015 & 2016 & 2017 & 2010 & 2016 \\
\hline $\begin{array}{l}\text { Net profit (loss), UAH } \\
\text { million }\end{array}$ & 17253,6 & 21413,4 & 102279,0 & 89816,3 & 78457,7 & 454,7 & 87,35 \\
\hline \multicolumn{8}{|c|}{ Enterprises that made a net profit } \\
\hline $\begin{array}{l}\text { as a percentage of the } \\
\text { total }\end{array}$ & 69,6 & 84,7 & 88,9 & 88,4 & 86,7 & 124,57 & 98,07 \\
\hline $\begin{array}{l}\text { financial result, } \mathrm{UAH} \\
\text { million }\end{array}$ & 22094,9 & 51668,0 & 127360,1 & 102496,1 & 91764,1 & 415,32 & 89,53 \\
\hline \multicolumn{8}{|c|}{ Enterprises that received a net loss } \\
\hline $\begin{array}{l}\text { as a percentage of the } \\
\text { total }\end{array}$ & 30,4 & 15,3 & 11,1 & 11,6 & 13,3 & 43,75 & 114,66 \\
\hline $\begin{array}{l}\text { financial result, UAH } \\
\text { million }\end{array}$ & 4841,3 & 30254,6 & 25081,1 & 12679,8 & 13306,4 & 274,85 & 104,94 \\
\hline $\begin{array}{l}\text { The level of profitability } \\
\text { of all activities, } \%\end{array}$ & 21,1 & 9,3 & 30,5 & 26,5 & 29,8 & 141,23 & 112,45 \\
\hline $\begin{array}{l}\text { The level of profitability } \\
\text { of operating activities, } \%\end{array}$ & 24,5 & 21,4 & 43,1 & 33,6 & 23,5 & 95,92 & 69,94 \\
\hline $\begin{array}{l}\text { Number of employees, } \\
\text { thousand people }\end{array}$ & 645,2 & 528,9 & 491,4 & 513,2 & 496,1 & 76,89 & 96,67 \\
\hline
\end{tabular}

Source: calculated according to State Statistics Service of Ukraine.

Traditional economic theory suggests that the purpose of agricultural enterprises is to maximize profits. Over the last twenty years there has been increasing criticism of this assumption. Galbraith (2013) assumes that it is not profit maximization but maximization of its sales that maintains profit margins to ensure the survival of an agricultural enterprise. In fact, there are many theories that have been developed with respect to the viability of the enterprise in its environment. There are many attributes and indicators that characterize excellent and efficient businesses. However, the most important and acceptable attribute is still the financial performance of an agricultural enterprise.

This article attempts to describe the relationship between strategy and financial resources of an enterprise. The empirical findings of strategic management scholars, over a long period of research, have shown that there are links between strategy and financial indicators of liquidity and solvency.

If financial indicators of liquidity and solvency are to be used to measure the efficiency of an

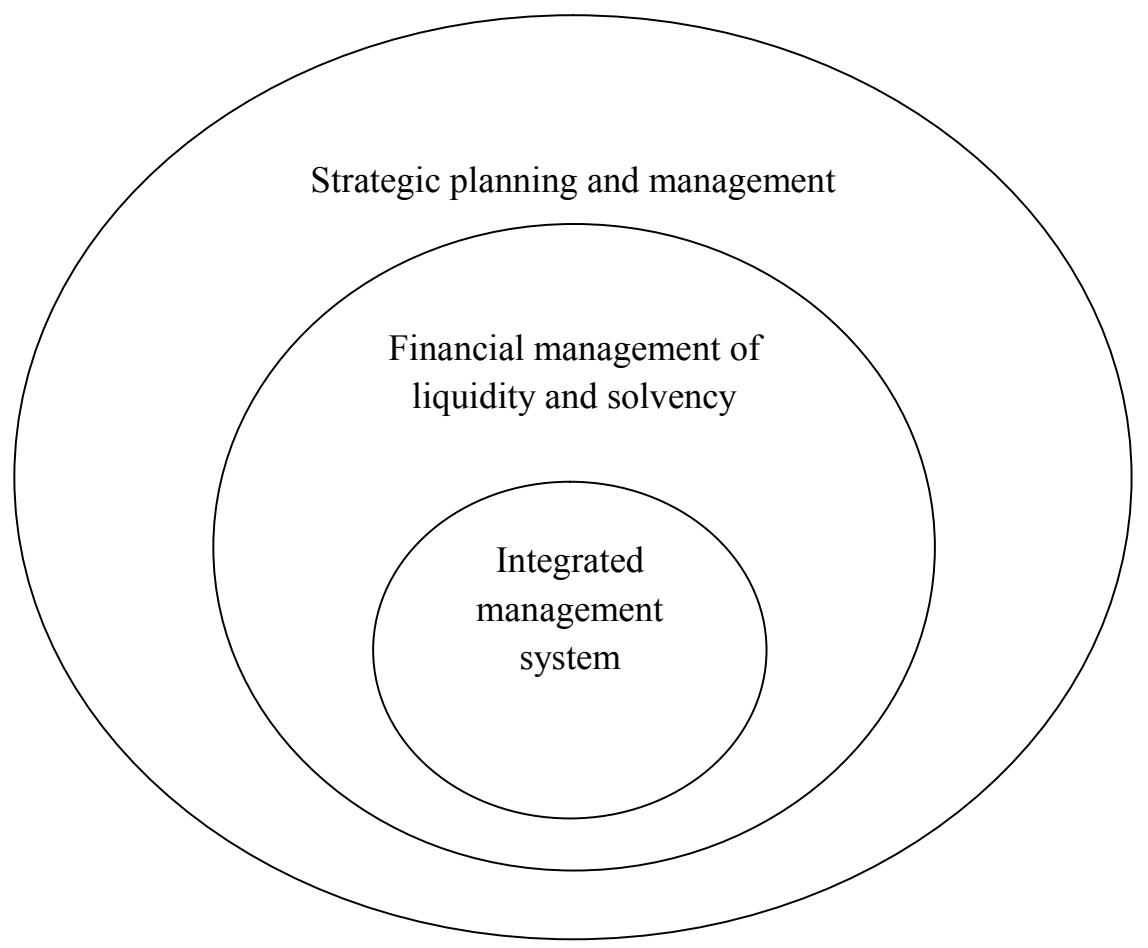

Fig. 1. Interconnection circle of the integrated production management systems of the agricultural enterprise 
agricultural enterprise's financial and economic performance, they are necessary to understand the goals and objectives of the business. Of course, one of the goals of an agricultural enterprise should be to make a profit. However, it should not be the only objective. The reason for this is that there are a number of other factors that have long been recognized as important for maintaining the solvency, liquidity and reliability of an agricultural enterprise, its growth over a period of time.

This conceptual scheme defines aspects of agricultural enterprise activity and uses three layers of integration:

1. The outer layer represents management in general: finance, production management and human resources management, marketing, strategic planning.

2. The middle layer is an operational process such as: product / process, production planning and production control.

3. The middle / third layer are: management of information resources and communications. The central idea of the circle is that there is an attempt to move away from the traditional view of liquidity and solvency towards total integration within the enterprise. The circle emphasizes the totality of integration. However, in order to meet the present and future challenges of the manufacturing industries, there is still room for improvement and development, as integration will take place not only within one enterprise but also between enterprises. The circle clearly has no external links between the business and its suppliers, subcontractors and/ or customers. This circle also includes indicators of the efficiency of financial and economic activity of an agricultural enterprise.

Failure of any of the elements of a circle of performance indicators can threaten natural growth and increase the profit that should occur every time a company bypasses the circle. Thus, the purpose of an agricultural enterprise must be to satisfy all the essential criteria on which success depends.

Thus, in their study of strategy and effectiveness, Ansoff and Sullivan (2003) describe a strategic success formula that states that a firm's profitability is optimized when its strategic behavior is consistent with the environment. The formula was developed over a 25-year period and has been field tested. They provide a formula called the Contingent Strategic Success Formula (CSSF), which says that in order to achieve optimal profitability, both strategic aggression and overall management response of an enterprise must be consistent with the level of environmental turbulence.

Therefore, the conceptual principles of financial management of agricultural liquidity and solvency are as follows:

- there is no single formula for success that guarantees optimal profitability for all agricultural enterprises;

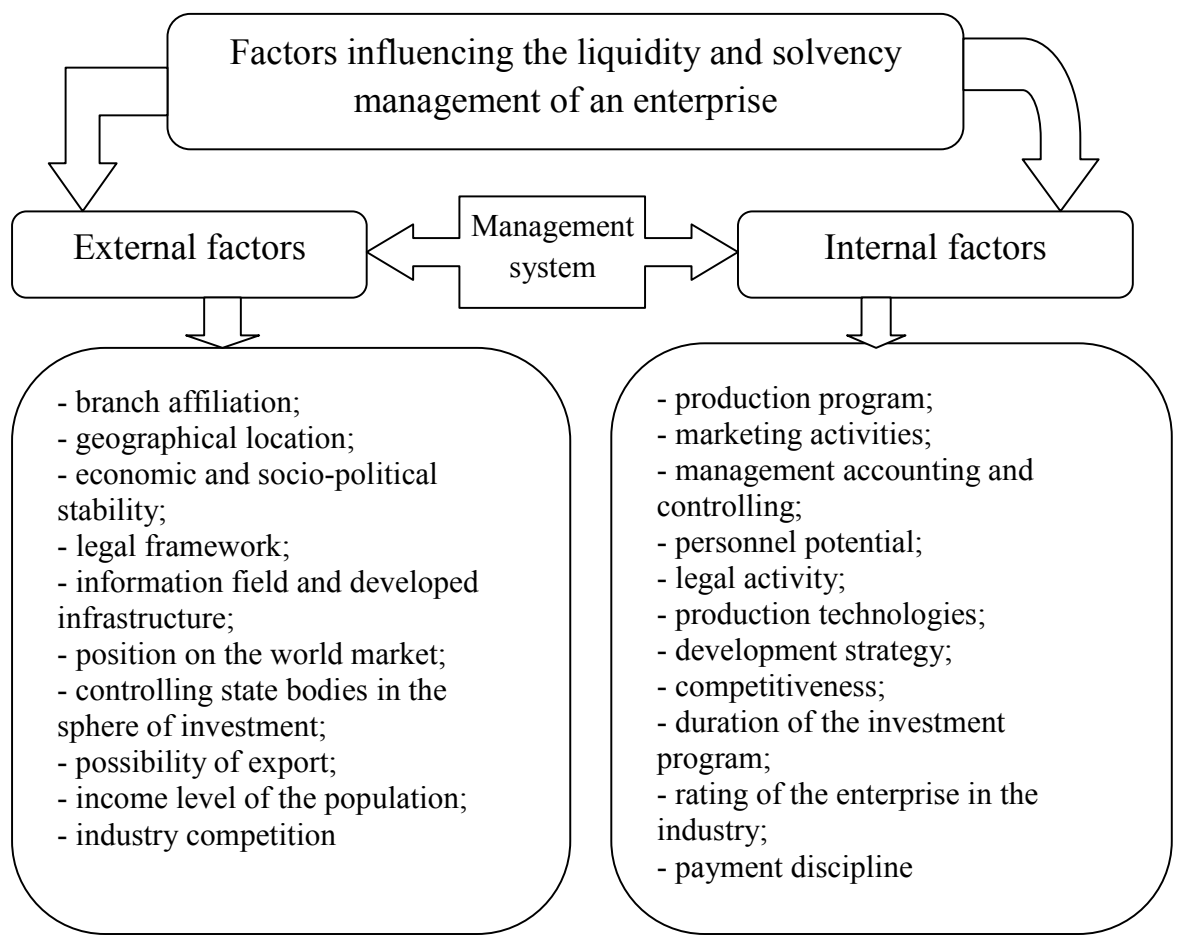

Fig. 2. Factors of influence on liquidity and solvency management of the enterprise

Source: Compiled by the authors. 
- Instead, there is a separate success formula for each environment and turbulence level;

- the strategic success formula provides a "conceptual umbrella" that defines the specific levels of environmental turbulence at which success is found;

- as the name implies, CSFF only studies the strategic behavior of the enterprise. Since strategic behavior (which shapes the profit potential of an agricultural enterprise in the form of new products, markets, technologies and competitive strategies), agricultural enterprises should also be tasked with optimizing their financial management of liquidity and solvency, which can achieve optimal profitability. The results of the study show that companies that achieve strategic success are successful in operational terms.

The above conceptual principles of agricultural liquidity and solvency management prove that there are links between the strategy and the financial results of the enterprise. The findings also support the argument that there is no single best strategy.

There are a number of measurements of financial solvency and liquidity indicators of agricultural enterprises, which are used for frequent analysis of the performance of the enterprise and include the analysis of ratios. In terms of ratio analysis, two main groups of financial ratios are described: those relating to profitability, liquidity and solvency. Return on Equity (ROCE) and Return on Equity (ROSF) are two factors that represent the return on the business. Liquidity ratios are coefficients that represent the potential solvency of an enterprise in the short term, while the turnover ratio is an indicator that represents the potential solvency of the enterprise in the long term.

Turnover or total sales are used to measure the gross income or sales of an agricultural enterprise for the year. Integrated indicators are a wellknown multivariate analysis system that is used to assess the overall financial condition of an agricultural enterprise and the probability of insolvency.

Financial Ratios Analysis is the systematic evaluation of the ratios of both internal and external financial statements in order to summarize key relationships and results for evaluating financial performance. Ratio analysis as a practical monitoring and performance enhancement tool is greatly enhanced when:

- relationships are analyzed on a regular basis and on an ongoing basis so that trends can be identified, trends identified and investigated;
- ratios prepared for an individual enterprise can be compared with other enterprises in the same industry. This process is greatly facilitated when an agricultural enterprise has ready access to comparative ratios prepared in a standardized manner.

Therefore, profit is obviously a key outcome in a fragile environment. And profitability is the reason that most businesses carry out financial and economic activities. Businesses are looking for better profitability, lower risk. Profitability ratios measure and help control revenue. The main relationships in this area are:

- return on equity (ROCE); and

- capital turnover (ROSF).

Of the above two types of ROCE ratios, it is more appropriate to evaluate the efficiency ratio in forming profitability. ROSF is more useful in assessing the ratio of net income to shareholder equity.

Analysis of solvency (or potential insolvency) has some limitations. Ratio analysis is required on the basis of the ordinary financial statements (balance sheets, operating reports, profit and loss statements), so that any prepared ratios relate to past conditions, whereas solvency applies to current ones. Conditions can change dramatically from the last balance sheet date, and an enterprise that was solvent at the time is experiencing difficulties, possibly due to the withdrawal of credit. Accordingly, any solvency ratios should be treated with caution and an adjustment made to take into account more relevant information.

It should be noted that liquidity ratios (or solvency ratios) measure the amount of cash to cover both current and long-term costs. These ratios are especially important for business support. Not paying bills due to cash shortages is the fastest way to get out of business. This argument is supported by the study that liquidity refers to an entity's ability to meet its short-term financial obligations as they mature.

Solvency ratios can be grouped into two categories, those related to short-term factors and those related to the long-term ability of an entity to meet all financial obligations, including those that are not currently payable. Some shortterm solvency ratios, such as the ratio of current to fast, are considered important in assessing the financial stability of an agricultural enterprise, in particular for financial analysts, investors, bankers and creditors. Two groups were recognized as valuable groups of ratios: those relating to current assets and current liabilities and those indicating the rate at which short-term assets are converted to cash. 


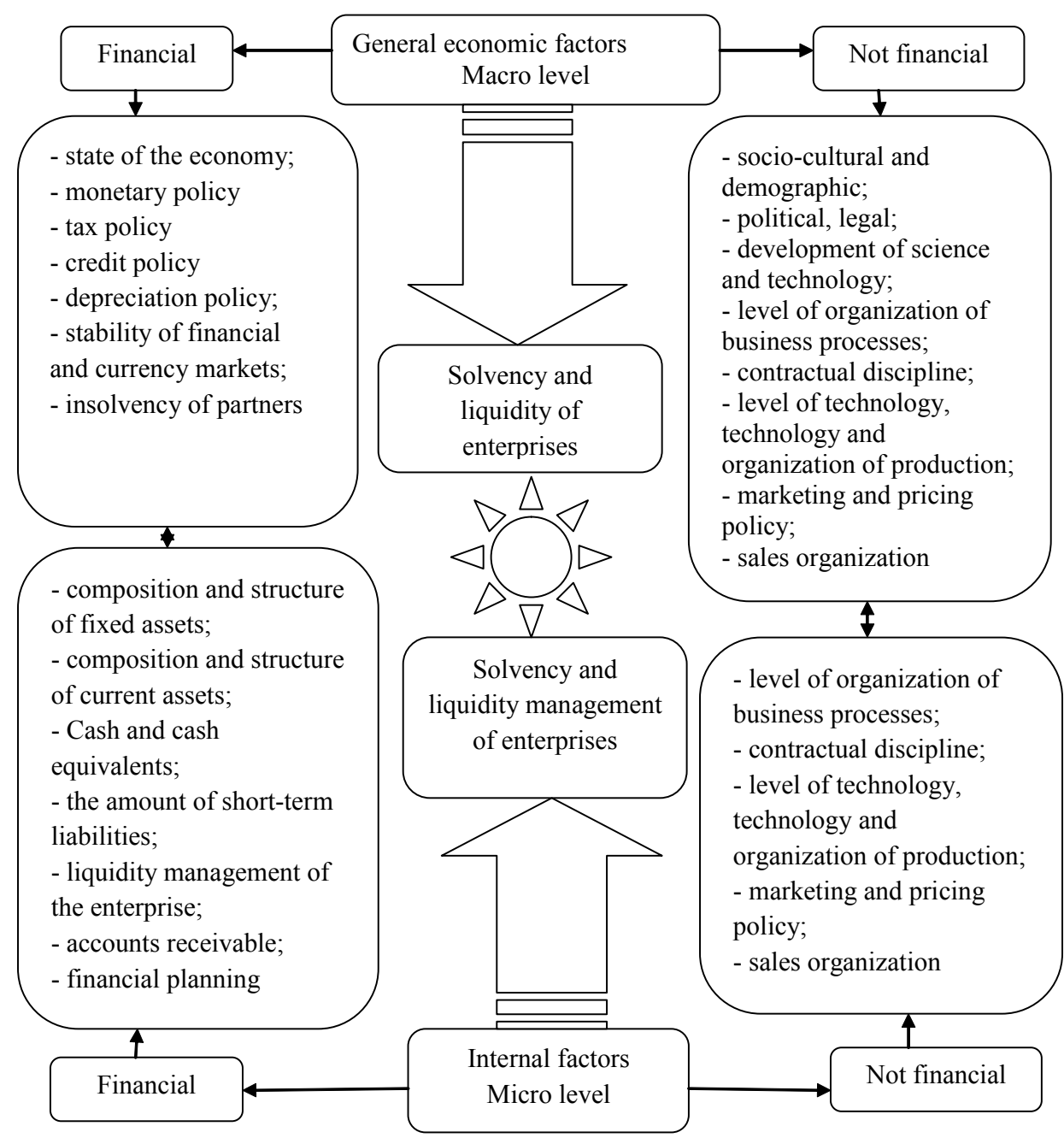

Fig. 3. Structural and logical scheme of factors influencing the management of solvency and liquidity of the company

Source: authors' own development.

Current ratio is an indicator that measures the ability to meet short-term liabilities. The standard for the current ratio is $2: 1$. An entity with a low current ratio may not be able to settle its accounts as quickly as necessary. On the other hand, a high ratio of current ratio means that money that could go into business is tied up in securities, cash or other secure assets.

It should be noted that the current ratio effectively estimates the working capital of the enterprise. As a rule, it is expected that it is within the range of values appropriate for enterprises in the industry. It is not correct to be dogmatic about the ideal value for a ratio, but analysts consider values in the range of 1.8 to 2.1 acceptable. The current ratio includes those assets and liabilities that have a life cycle that is measured in months rather than weeks. While this aspect of solvency is large, instant liquidity is also important. This is an indicator of instant liquidity that eliminates stocks and thus focuses on more liquid assets such as cash and receivables. Again, it may not be an exact norm, but an acceptable range of values for a ratio between 1: 1 and 0.8: 1 (quick assets: current liabilities) is acceptable.

The day-to-day position of a liquidity business depends largely on the speed at which cash flows flow into the business from ordinary operations. These operations involve the conversion of inventories into sales, and hence into receivables and the subsequent conversion of receivables into cash. The following two ratios give some idea of an entity's ability to generate cash from ordinary activities (Ratio of average turnover $=$ value of goods sold during the period/average stocks held during the period; average maturity $=$ accounts receivable at the balance sheet date/ average daily credit sales).

The average asset turnover ratio varies greatly between industries, comparing to well-known enterprises and the prior periods of the enterprise itself. Long-term solvency ratios are focused on the 
long-term financial stability and structure of the enterprise and are usually of the greatest interest to financial analysts and investors. A number of coefficients can be calculated in this area.

Generalizing approaches to determining the main influencing factors is allowed us to form a scheme and to determine the peculiarities of influence on the activity of an insolvent enterprise (Fig. 3).

The evaluation of the solvency and liquidity management efficiency is carried out according to the following system of criteria:

- the change of the most important indicators of economic and financial activity and financial condition of the enterprise during the management period has been achieved;

- the speed of obtaining positive changes per unit of time, that is, the increase in generalized economic indicators obtained in one time interval (week, month, quarter); effect;

- cost-effectiveness of obtaining a positive

- sufficiency of changes to restore the viability of the enterprise.

Thus, the solvency and liquidity management of the enterprise is based on a thorough analysis of the financial and economic condition of the enterprise and the development of measures to improve liquidity and solvency, which allows the company to anticipate and avoid negative situations, as well as to increase the efficiency of its activity due to the obtained reliable information. The source of such information can be economic expertise, as a resource for identifying economically justifiable causes of insolvency.

The role of managing solvency and liquidity of an enterprise in ensuring the effective development of the enterprise is, in particular, that it allows to carry out:

1) attracting attention to strategically significant cost objects and calculating their cost in strategic planning and analysis;

2) assessment and control of management decisions affecting financial and economic activities;

3) information support for the analysis of the value chain, identification of opportunities for optimization of the enterprise;

4) formation of cost targets and assessment of their achievement;

5 ) identification of cost carriers and regulation of cost factors;

6) assessing the effectiveness of business processes in terms of resource intensity and value creation and value for the consumer;
7) cost / benefit comparison (profit, consumer value, competitive advantage, etc.);

8 ) the calculation of the cost of the product at all stages of the life cycle;

9) performance evaluation of individual segments and others.

It should be borne in mind that solvency and liquidity management is carried out both at a purely functional level, within the specialized management services, and at the level of specific places of their occurrence. In accordance with the vision of the goals of the enterprise solvency and liquidity management defines the tasks that are solved within the enterprise management system as a whole and its individual functions, ensures their competitiveness with the goals of the enterprise and mutual consistency.

\section{CONCLUSIONS AND PROSPECTS FOR FURTHER RESEARCH}

Thus, having studied the conceptual principles of liquidity management and solvency of the company, we can draw some conclusions. In order to ensure the efficient operation of the enterprise, it is necessary to separate the liquidity and solvency management system from the general system. Budgeting, regulation of monitoring and operational procedures, and the establishment of an orderly system of analytical reports and discussion of results and issues are needed. In turn, this will allow the company to optimize costs, cost factors and ensure the implementation of the strategy of effective enterprise development.

Therefore, today there is a wide variety of techniques for determining the liquidity and solvency of an enterprise. In general, all the methods of estimation of liquidity and solvency in relation to the source of the source information developed in the domestic and world practice can be roughly divided into three large groups: 1) techniques based on different expert assessments; 2) techniques based on statistical information; 3 ) combined techniques.

The prospect of further research is the development of an economic and mathematical model for managing the liquidity and solvency of the enterprise.

\section{$\Lambda$ ітература:}

1. Аемчук H.I., Халатур C.M., Хідірян M.O. (2017). Теоретичні основи аналізу фінансового стану сільськогосподарських підприємств. Економіка та суспільство, 9, С. 396-400.

2. Аержавний сайт статистики України. URL: http://www.ukrstat.gov.ua/ 
3. Agricultural support (2017). Official website of the Organization for Economic Cooperation and Development (OECD). Retrieved from https:/ /data.oecd.org/agrpolicy/ agricultural-support.htm

4. Dragana, D. (2016). Comparative analysis of functional food produce rs' profitability in Serbia: A leaderfollower relation. Economics of Agriculture, 2, pp. 547-566.

5. Hudym K., Khalatur S. (2016). Systematisation and analysis of MNCs' models of conduct for entering the national agrarian markets. Економічний часопис-XXI, 5-6, pp. 34-37.

6. Khalatur S. (2015) Mechanism of adaptation of agroindustrial complex of Ukraine in the conditions of global food problem. Visnyk Dnipropetrovs' koho derzhavnoho ahrarno-ekonomichnoho universytetu, 1, pp. 114-116.

7. Khalatur S.M. (2017). Innovative doctrine development of agriculture growth of Ukraine. Технологический аудит и резервы производства. Vol. 4, 5 (36), pp. 19-26.

8. Gleim I., \& Flesher D. (2018). CMA Review, Part 2: Financial Decision Making (16th ed.). Gleim Publications. Retrieved from https://www.amazon.com/CMAReview-Part-Financial-Decision/ $\mathrm{dp} / 158194201 \mathrm{X}$

9. Mohammad Fawzi Shubita (2019). "The impact of working capital management on cash holdings of large and small firms: evidence from Jordan". Investment Management and Financial Innovations, 16(3), pp. 76-86. doi:10.21511/ imfi.16(3).2019.08

10. Ruslan Mann, Victor Martinovich and Oksana Yakusheva (2018). "The peculiarities of working capital management at agroindustrial enterprises of Ukraine". Problems and Perspectives in Management, 16 (2), pp. 260-268. doi:10.21511/ppm.16(2).2018.24

11. Ruslan Mann and Alexander Bilyk (2017). "Monitoring the factors influencing the efficiency of agricultural enterprises' working capital of Ukraine". Problems and Perspectives in Management, 15(4), pp. 161-167. doi:10.21511/ppm.15(4).2017.14

12. Ulanchuk V., Zharun O., Sokolyuk S., \& Tkachuk, S. (2017). "Investment needs assessment of Ukrainian agricultural enterprises". Investment Management and Financial Innovations, $14(1-1)$, pp. 181-190. http://dx.doi. org/10.21511/ imfi.14(1-1).2017.04

\section{References:}

1. Demchuk, N.I. Khalatur, S.M. and Khidiryan, M.O. (2017), "Theoretical bases of analysis of the financial state of agricultural enterprises", Economics and Society, vol. 9, pp. 396-400.

2. State Statistics Service of Ukraine (2019), available at: http://www.ukrstat.gov.ua/ (Accessed 10 Nov 2019).

3. Official website of the Organization for Economic Cooperation and Development (OECD) (2017), "Agricultural support", available at: https:/ /data.oecd.org/agrpolicy/agricultural-support.htm (Accessed 10 Nov 2019).

4. Dragana, D. (2016), "Comparative analysis of functional food produce rs' profitability in Serbia: A leaderfollower relation", Economics of Agriculture, vol. 2, pp. 547-566.

5. Hudym, K. and Khalatur, S. (2016), "Systematisation and analysis of MNCs' models of conduct for entering the national agrarian markets", Economic Annals - XXI, vol. 5-6, pp. 34-37.

6. Khalatur, S. (2015), "Mechanism of adaptation of agroindustrial complex of Ukraine in the conditions of global food problem", Visnyk Dnipropetrovs' koho derzhavnoho ahrarno-ekonomichnoho universytetu, vol. 1, pp. 114-116.

7. Khalatur, S.M. (2017), "Innovative doctrine development of agriculture growth of Ukraine", Technological audit and production reserves, vol. 4, 5 (36), pp. 19-26.

8. Gleim, I. and Flesher, D. (2018), "CMA Review, Part 2: Financial Decision Making", 16th ed., Gleim Publications, available at: https:// www.amazon.com/CMAReview-Part-FinancialDecision/dp/158194201X (Accessed 10 Nov 2019).

9. Shubita, M. F. (2019), "The impact of working capital management on cash holdings of large and small firms: evidence from Jordan", Investment Management and Financial Innovations, vol. 16 (3), pp. 76-86. doi:10.21511/ imfi.16(3).2019.08

10. Mann, R. Martinovich, V. and Yakusheva, O. (2018), "The peculiarities of working capital management at agroindustrial enterprises of Ukraine", Problems and Perspectives in Management, vol. 16 (2), pp. 260-268. doi:10.21511/ ppm.16(2).2018.24

11. Mann, R. and Bilyk, A. (2017), "Monitoring the factors influencing the efficiency of agricultural enterprises' working capital of Ukraine", Problems and Perspectives in Management, vol. 15 (4), pp. 161-167. doi:10.21511/ppm.15(4).2017.14

12. Ulanchuk, V. Zharun, O. Sokolyuk, S. and Tkachuk, S. (2017), "Investment needs assessment of Ukrainian agricultural enterprises", Investment Management and Financial Innovations, vol. 14 (1-1), pp. 181-190. http://dx.doi. org/10.21511/ imfi.14(1-1).2017.04

Стаття надійшла до редакиії 06.12.2019 p. 